\title{
ENVIRONMENTAL ASPECTS OF COASTAL EARTH STRUCTURES MADE OF SOIL-ASH COMPOSITES
}

\author{
Rafał Ossowski, PhD \\ Gdansk University of Technology, Poland
}

\begin{abstract}
This paper presents an innovative technology of building the coastal dams with the use of soil-ash composites. A natural-scale test stand and results of the performed environmental tests are presented; they have been compared with standards for purity of soils and waters. Also, an analysis of the obtained results and discussion of trends and anomalies in the observations, are given.
\end{abstract}

Keywords: marine environment protection, soil-ash composites, construction monitoring

\section{INTRODUCTION}

Soil structures in coastal zone generally fulfil protective functions - they are aimed at direct protection of coast or/ and a greater area of land, e.g. in case of depression terrains. In Poland are more often used the soil structures ( also those reinforced ) to serve as one of coast protection elements (storm embankments etc), however in some EU countries such as Germany, Denmark, the Netherlands, a relatively large part of coastal structures constitute protection embankments which protect firm land against water thrust resulting first of all from sea tides and, in the second order, from storms.

Building material for erecting soil coastal structures is won from sites located possibly near the building site, because of transport cost. However in case of soil work of a large volume, local resources of crush stone aggregates do not constitute sufficient reserves and then one reaches for material from more distant sources. On the other hand, in coastal zone the regular dredging of water fairways is carried out from which a large supply of dredge winning is available, they may serve as a substitute of natural aggregates in erecting the soil structures.
In this paper is presented an innovative technology for building soil embankment with the use of a composite soil [1]: a mixture of silt-up material won during dredging work and bottom ash obtained from coal combustion in a heat \& power and station. An important aspect in utilizing waste and secondary materials for building the coastal structures is to ensure appropriate protection for the marine environment. Therefore the issue discussed further in this paper are selected environmental investigations carried out on a real soil structure. A part of them was conducted in the frame of preliminary experiments on selection of structural material, and another part - in the frame of monitoring the ready- to- use structure. The presented results are merely a part of the research project in which physical, chemical and mechanical aspects of composite soils were investigated [2], as well as mechanical

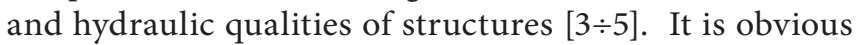
that such research does not cover all the possible spectrum of analyses associated with the monitoring of coastal and offshore objects, which connects such distant domains like the investigation of non-linear permeability features of soil medium itself [6], laser coast scanning [7] or acoustic test methods [8-11]. 


\section{EXPERIMENTAL DIKE}

Investigations of composite soils were performed on an experimental test stand (in natural scale) placed close to Gdańsk and built in the frame of the EU project DredgDikes $[1,5]$ which has been aimed at the developing of innovative technology of building soil structures. A superior task of the project was to investigate usability of fine-grain winning materials as well as ash-sand composites for erecting sea - coast and river embankments.

For this reason the body of the experimental dike at Gdańsk was designed on the basis of a composite of a sand dredged out of the river bed of the Dead Vistula, and a bottom ash from EC2 heat \& power station at Gdańsk.

Various materials forming the composite were tested in a laboratory - both in the phase of designing and during the erecting of dike structure [2]. The tests were aimed at optimization of material in the sense of its mechanical properties ( compactibility and stability of the body) hydraulic ones (permeability, leaching the toxic substances ) as well as resistance of the structure against long-lasting hydraulic loading and erosion in case of a water flow over crown of the body.

The preliminary laboratory tests were aimed at determination of optimum proportion of ashes and sand to form a soil composite for dike core. The tests resulted in knowledge of mechanical properties of the composite, a. o. its compressibility, strength parameters, as well as compactibility and water permeability. The tested parameters were determined for component materials (sand, ash) as well as their mixtures in appropriate proportions changed step by step by10\% [2].

As a result of the preliminary tests the optimum composite $70 / 30$ ( ash/ sand) was selected to be the basic material for building the experimental dike. As a matter of fact, such mixture has a relatively high filtration ratio $\left(1.35 \cdot 10^{-5} \mathrm{~m} / \mathrm{s}\right)$, however, a decrease in hydraulic conductance resulting from consolidation of the dike body as well as cementation due to puzzolan features of ashes, were observed. The tests conducted on specimens taken out from the experimental dike showed a drop in filtration rate by $40 \%$ per 180 days [2]. This was the composite used for building the test stand in the form of the experimental dike of $3 \mathrm{~m}$ in height, placed at Trzcinisko village close to Gdańsk [1,3]. Slope of its scarps was 1:2, breadth of crown - $3 \mathrm{~m}$, full footing breadth - $15 \mathrm{~m}$ and length - 24 $\mathrm{m}$. The test stand itself covered $4 \mathrm{~m}$ segment extracted from the dike by means of tight walls which permit to obtain plane flow necessary for filtration and overflow investigations at controlled water level (Fig.1, 2).

As mentioned above, the experimental dike is relatively homogenous, built of the composite made from bottom ashes in $70 \%$ and sand in 30\% ( marked : 70/30 composite ). Under the test stand an isolation clay layer of $0,5 \mathrm{~m}$ in thickness was placed. Additionally, the coating layers were applied : of $50 \mathrm{~cm}$ thick clay on the water-exposed side and $30 \mathrm{~cm}$ thick mixture of dusts and Tefra ${ }^{\circledR}$ binder ( produced on the basis of volatile ashes ) to form the upper layer on the air-exposed side of the dike (protection against erosion). All the object was covered by plants ( grass).

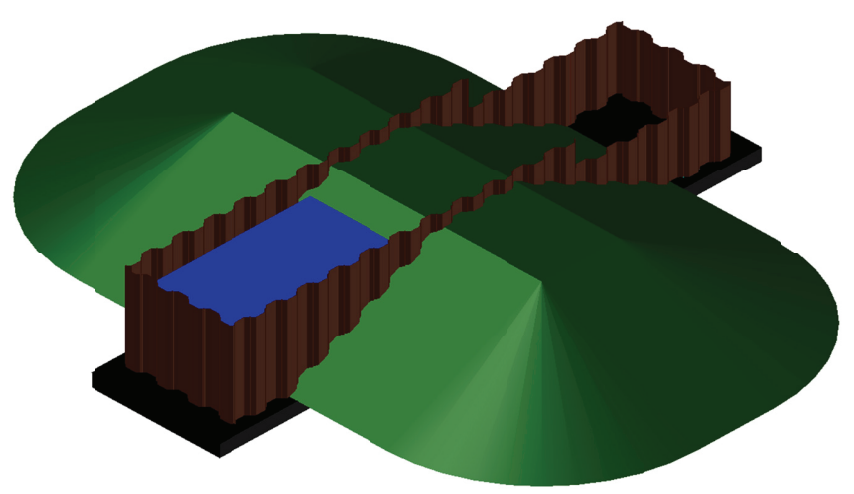

Fig.1. Model 3D model of the test stand;marking colours stand for : green dike body, bronze - tight walls, blue - water, black - bottom tightening (on ground base)

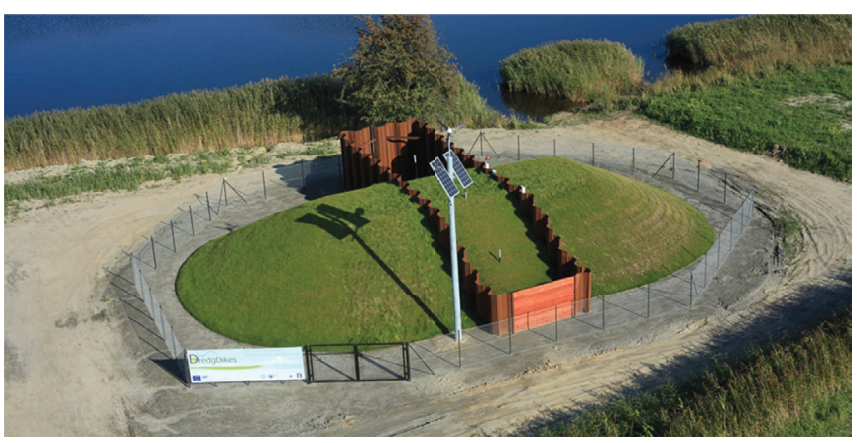

Fig. 2. The ready-to-use test stand-aerial view

\section{CHARACTERISTICS OF STRUCTURAL MATERIALS}

The composite soil for building the dike consisted of the mixture of the winning dredged out of the bed of the Dead Vistula ( river sand ), and the by-product of coal combustion in the heat \& power station (bottom ash). Short characteristics of the materials are presented below. A. Dredged winning

The dredged winning is a deposit material which has been won from the bed of basins or rivers/canals. The natural sedimentation process of drifting materials and aggregates leads to forming the sediments and, consequently, decreasing the depth of reservoirs and waterways. In case of sailing waters the sediments are to be removed regularly by dredging. The dredged winning is consisted of organic parts ( micro-organisms and remains of plants and animals) and non-organic ones (mainly sand and dust). Content and characteristics of a sediment and, consequently, dredged winning, depends on geomorphology of a given reservoir or drainage basin, as well as on hydrodynamic and hydro-geologic processes which occur in surface waters. A separate issue is salinity of deposit and its chemical content. 
Dredging operations provide large amount of soil materials which may be utilized for building soil structures. In Poland the yearly balance of dredging output from the river and sea waterways amounts to about $1,1 \mathrm{mln}^{3}$ (acc. data of Maritime Administration Office in Gdynia), however in Germany about $41 \mathrm{mln} \mathrm{m}^{3}$ of dredged winning is reached from the dredging of sea waterways and about $5 \mathrm{mln} \mathrm{m}^{3}$ - from inland waterways [12].

In many cases the dredged winning may be considered a material which is capable of substituting or lowering the demand for natural raw materials (including aggregates) that is conducive to environment protection. A crucial factor deciding on its possible application is lack of contamination of bed sediments, however the bettering of a slightly contaminated winning is also economically justified.

\section{B. Coal combustion by-products ( CCP)}

The by-products of coal combustion come from power plants firing hard or brown coal. Main admixtures of hard and brown coal are of mineral kind such as quartz, silt, calcite and slates. Hence, amount of the CCP produced by a power plant depends on a kind and volume of coal fired in boilers as well as on content of minerals in coal ( combusting technology is of a secondary importance). CCP amount produced worldwide is estimated to reach about $550 \mathrm{mln} \mathrm{t} /$ year, out of which 95 $\mathrm{mln} \mathrm{t} /$ year is covered by EU countries [13].

The CCP may be classified according to mineral content of coal as well as technology of its combustion. The main part of it is consisted of : fly ash, bottom ash, boil slag as well as ash from fluidal boilers (FBC) . Apart from the above mentioned components also products of sulfur removal from exhaust gases such as plaster, wet desulfurization products (FGD) as well as semi-dry absorption products (SDA). Fly ash is formed from fine grain particles of 1 up to 100 microns in size (average granulation is in the range of 20 - 25 microns). Bottom ash is a granular material consisted of bigger particles (dusty and sandy) of 0.1 to $50 \mathrm{~mm}$ in diameter.

Chemicalcontent of theashesisdeterminedbychemicalcontent of coal fuel and its combustion technology. Ash is composed of typical minerals which form most of the earth crust rocks. Al-silicates , $\mathrm{Ca}, \mathrm{Fe}$ and $\mathrm{Mg}$ - oxides form more than 90 $\%$ of mass of typical ashes. The remaining compounds of the elements such as : $\mathrm{Na}, \mathrm{K}, \mathrm{Ti}$, and $\mathrm{S}$ cover about $8 \%$ of ash mineral content, and the trace elements such as As, Kd , $\mathrm{Pb}$ and $\mathrm{Se}-$ no more than $1 \%$ of the content. In opinion of naturalists these are the elements which potentially endanger the natural environment in case of their uncontrolled release into e.g. the water environment. Basic chemical properties and reactivity of the CCPs are determined by content of $\mathrm{Ca}$, Fe and $\mathrm{S}$ compounds. Ashes produced in combustion process of brown coal and bitominous shales have a relatively high content of calcium (usually over $15 \%$ of $\mathrm{CaO}$ ), that generates seepages of alkaline character $(\mathrm{pH}=11 \div 12)$. Ashes from hard coal combustion contain generally much less $\mathrm{Ca}$ and produce solutions of in between slightly acid and slightly alkaline character $(\mathrm{pH}=5 \div 10)[1]$.

\section{ENVIRONMENTAL INVESTIGATIONS}

\section{A. Legal regulations}

Permissible concentration of contaminations in soil structures are not subjected to separate legal regulations in Poland. One may however relate to regulations dealing with purity of soils. The act in force in this matter is the Decree of Ministry of the Environment, of September 1,2016 on the method of carrying out assessment of soil surface contamination (Dz.U.2016 poz.1395) [22]. It distinguishes soil categories depending on their use. Tab. 1 shows permissible contents of substances which cause risk of contamination to soils ( given in the most restrictive requirements), for selected indices of contamination.

Tab. 1. Selected permissible values of contaminations contained in soil (for the highest class of purity) [22]

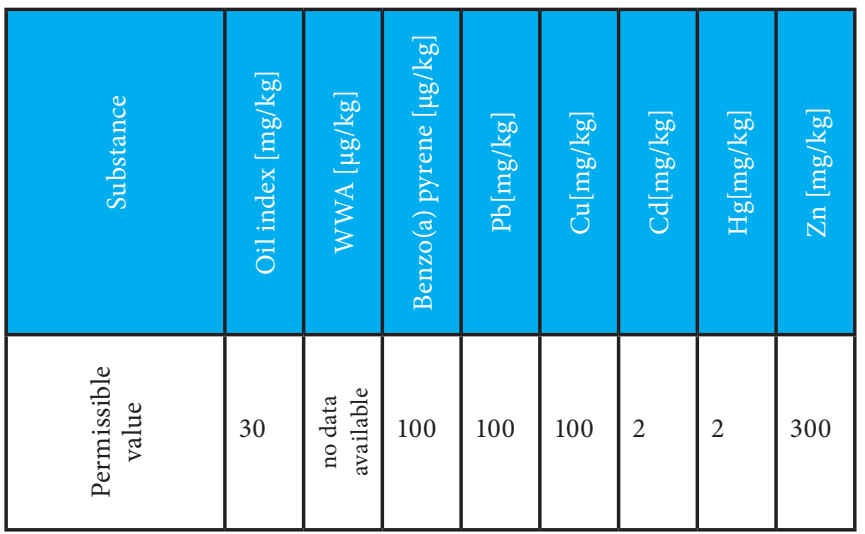

Another source which soil contamination level maybe referred to are the recommendations of the Institute of Soil Cultivation, Fertilization and Science on Soils in Puławy [14]. The recommendations propose classification of soils into 6 categories , beginning from the level " 0 " non-contaminated soils having natural content of heavy metals, and ending on the level "V" - very heavy contaminated soils, generally excluded from agriculture production. However it should be taken into account that the recommendations concern only a $20 \mathrm{~cm}$ layer of soil in the context of agriculture production hence any comparison with a soil for building purposes is not fully authoritative ( reliable). Tab. 2 presents a comparison of the requirements for light non-contaminated soils (of the level "0") with those for soils of an elevated content of metals ( of the level "1").

Tab. 2. Natural content of heavy metals in soil ( a non-contaminated soil) [14]

\begin{tabular}{|c|c|c|c|c|c|}
\hline Substance & $\begin{array}{l}\overline{\infty 00} \\
\frac{0}{00} \\
\underline{\Xi} \\
\vec{a}\end{array}$ & $\begin{array}{l}\overrightarrow{00} \\
\frac{7}{b 0} \\
\underline{\Xi} \\
\vec{J}\end{array}$ & 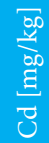 & 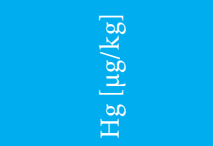 & 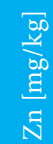 \\
\hline Level 0 & 30 & 15 & 0,3 & $\begin{array}{l}\text { lack of } \\
\text { recommendation }\end{array}$ & 50 \\
\hline Level 1 & 70 & 30 & 1 & $\begin{array}{l}\text { lack of } \\
\text { recommendation }\end{array}$ & 100 \\
\hline
\end{tabular}


As far as contamination of filtering water seepage through the dike body is concerned, the measured values may be compared with the recommendations for purity of water. Such recommendations are contained in The Decree of Ministry of the Environment, of November 9, 2011, on the method of classification of homogenous parts of surface water areas and the environmental quality standards for priority substances (Dz.U.2011.257.1545) [23], selected permissible values of which are given in Tab. 3 .

Tab. 3. Selected permissible values of contaminations for coastal waters of the highest category of purity [23].

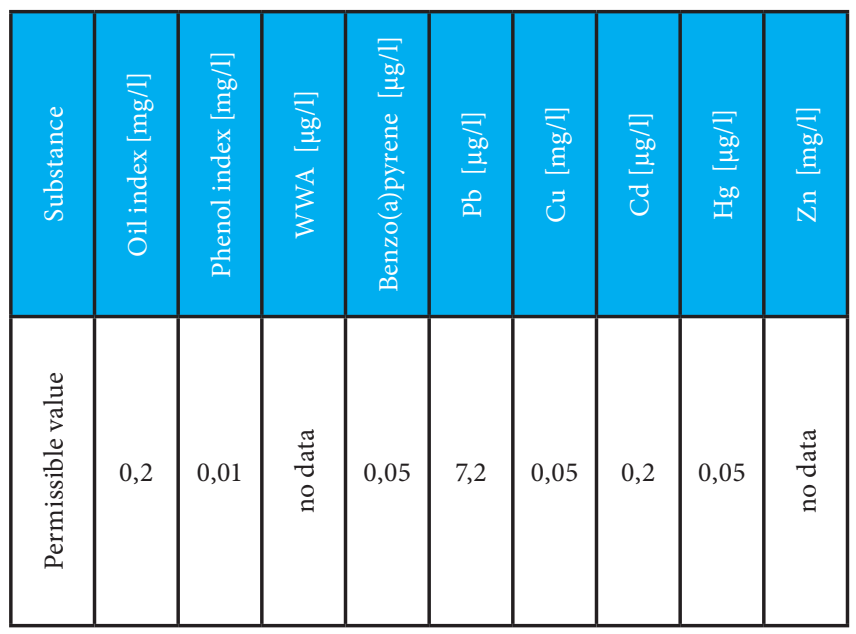

Another important document is The Decree of Ministry of the Environment, of November 27,2002 , on the requirements for surface water used for supplying potable water to population (Dz.U.2002.204.1728) [24]. Tab. 4 shows selected permissible values of contaminations according to the above mentioned decree, contained in the water intended to be supplied as potable for population.

Tab. 4 Selected permissible values of contaminations contained in water intended to be supplied as potable [24]

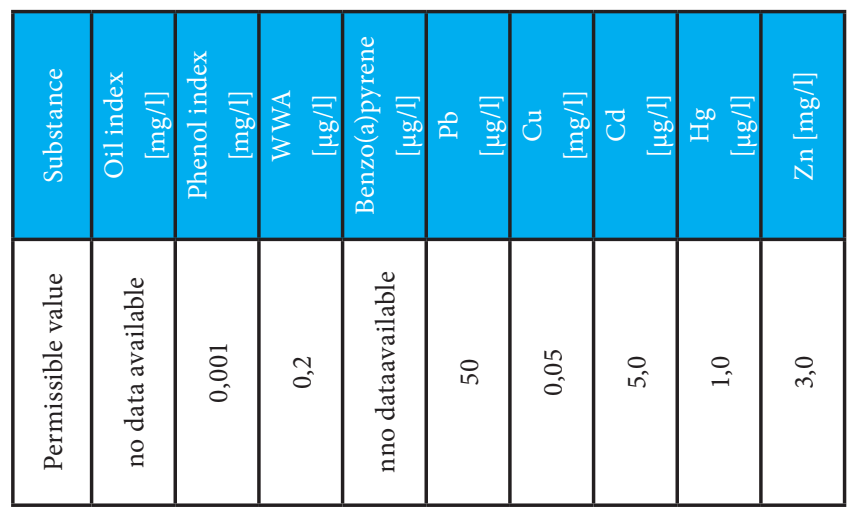

The presented regulations are used as the references for the investigations conducted on the test stand described below.

\section{B. Results of the laboratory analyses}

The investigations of contaminations in the composite soil ( silt + ash ) as well as in the water filtering through the dike were an element of environmental control of the project.
Before the starting of building operations, specimens of both component materials, i.e. the ash from the heat \& power plant and the sand from dredging work, were tested to control their contamination level. After the completing of the test stand (in the frames of the planned monitoring of the environment), were performed analyses of contamination of water samples taken directly from the test stand. The samples were taken from six testing points : the upper reservoir, four piezometric holes and bottom seepage water (Fig. 3). Two series of the tests were performed in simulated hydrodynamic conditions of water flow through the dike body. The chemical analyses were conducted by accredited laboratories with the use of the methods of atomic and emission spectrometry ( analysis of heavy metals ), gas chromatography (hydrocarbons) as well as spectrophotometry.

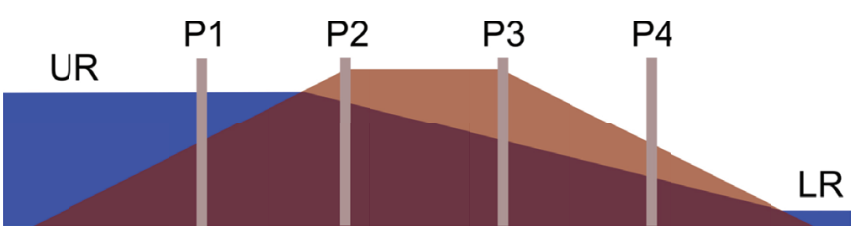

Fig. 3 Cross-section of the dike with the indicated points from where the water samples were taken for the analysis: UR - upper reservoir, P1...P4piezometric holes, $L R$ - lower reservoir

Tab. 5 presents the results of the laboratory tests performed before starting the building work. Specimens of the sand tilt and bottom ash were tested separately.

Tab. 5. Collected results of environmental analyses of composite component materials

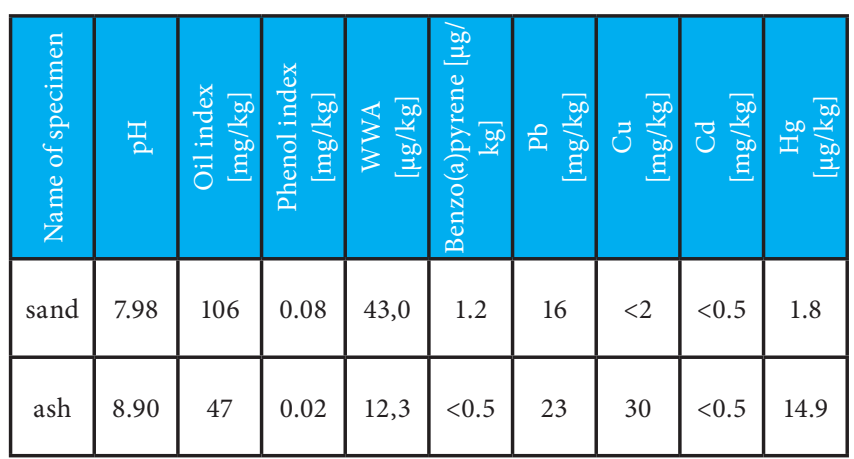

Comparing the obtained results with the requirements of the Decree of Ministry of Environment issued in 2016 [22] (Tab.1) one can observed that heavy metals contained in both the components satisfy the soil purity criteria, not yet approaching the upper limit of the standard. As far as organic contaminations are concerned, this is benzo(a) pyrene which shows concentrations much lower than the permissible levels, however oil index exceeds the standard level significantly. The comparison of concentrations of the tested metals with the levels recommended in the guidelines [14] (Tab. 2) indicates that both the soil composite components satisfy the requirements of the level "1", i.e. they can be numbered among the soils of elevated content of heavy metals 
( however they are still considered not contaminated soils ). In the second phase of the project, after erection of the test stand, two series of water contamination tests were conducted in hydrodynamic unsteady flow conditions so as to check in natural scale whether there is any hazard of contamination leaching from the dike body. The entire test stand was isolated from parent ground by means of $0,5 \mathrm{~m}$ layer of clay in order to eliminate seepage into natural soil. The specimens were taken in two test series at 20 days interval. Tab. 6 and 7 present the obtained values of selected concentrations and contamination indices in particular measurement points indicated in Fig. 3. The concentrations of all the contaminations in water are significantly higher in comparison with contaminations of the soil composite components. In Fig. $4 \div 7$ are directly compared more interesting test results from both experiments, i.e. $\mathrm{pH}$ reaction, WWA content, concentration of $\mathrm{Cu}$ and phosphates . From $\mathrm{pH}$ reaction results it may be concluded that water inflow to the piezometer 1 installed relatively near the upper reservoir, runs very fast ( there is no increase in $\mathrm{pH}$ reaction as a result of alkaline character of ash-soil composite ). The $\mathrm{pH}$ reaction values in the piezometers 2,3 and 4 are elevated ( due to $\mathrm{pH}$ reaction of the composite) and drop to their initial values in the lower reservoir.

Tab. 6. Collected results of chemical analyses of the water filtering through the dike - the experiment 1 (blue marked values - below detection limit)

\begin{tabular}{|c|c|c|c|c|c|c|c|}
\hline Indices & Unit & UR & P1 & P2 & P3 & P4 & LR \\
\hline $\mathrm{pH}$ & $\mathrm{mg} / \mathrm{l}$ & 7,92 & 7,77 & 9,55 & 9,47 & 9,60 & 7,61 \\
\hline Oil index & $\mathrm{mg} / \mathrm{l}$ & 0,1 & 0,1 & 0,1 & 0,1 & 0,2 & 0,1 \\
\hline $\begin{array}{l}\text { Phenol } \\
\text { index }\end{array}$ & $\mathrm{mg} / \mathrm{l}$ & 0,01 & 0,01 & 0,01 & 0,01 & 0,01 & 0,01 \\
\hline $\begin{array}{c}\text { Benzo }(a) \\
\text { pyrene }\end{array}$ & $\mu \mathrm{g} / \mathrm{l}$ & 0,0025 & 0,003 & 0,0025 & 0,0025 & 0,0025 & 0,0596 \\
\hline WWA & $\mu \mathrm{g} / 1$ & 0,010 & 0,010 & 0,010 & 0,010 & 0,010 & 0,172 \\
\hline Benzene & $\mu \mathrm{g} / \mathrm{l}$ & 0,5 & 0,5 & 0,5 & 0,5 & 0,5 & 0,5 \\
\hline $\mathrm{Zn}$ & $\mathrm{mg} / \mathrm{l}$ & 0,92 & 1,30 & 0,34 & 2,30 & 1,30 & 1,10 \\
\hline $\mathrm{Cd}$ & $\mu \mathrm{g} / \mathrm{l}$ & 0,64 & 0,1 & 0,2 & 1,9 & 0,1 & 0,1 \\
\hline $\mathrm{Cu}$ & $\mu \mathrm{g} / \mathrm{l}$ & 11,0 & 4,3 & 10,0 & 13,0 & 3,3 & 4,9 \\
\hline $\mathrm{Pb}$ & $\mu \mathrm{g} / \mathrm{l}$ & 1,5 & 1,0 & 1,0 & 3,2 & 1,0 & 1,0 \\
\hline $\mathrm{Hg}$ & $\mu \mathrm{g} / \mathrm{l}$ & 0,02 & 0,01 & 0,01 & 0,03 & 0,01 & 0,01 \\
\hline Phosphates & $\mathrm{mg} / \mathrm{l}$ & 1,32 & 1,44 & 0,28 & 0,16 & 0,18 & 0,35 \\
\hline
\end{tabular}

Tab. 7. Collected results of chemical analyses of the water filtering through the dike - the experiment 2 (blue marked values - below detection limit)

\begin{tabular}{|c|c|c|c|c|c|c|c|}
\hline Indices & Unit & $\mathrm{UR}$ & $\mathrm{P} 1$ & $\mathrm{P} 2$ & $\mathrm{P} 3$ & $\mathrm{P} 4$ & $\mathrm{LR}$ \\
\hline $\mathrm{pH}$ & $\mathrm{mg} / \mathrm{l}$ & 7,88 & 7,73 & 9,00 & 9,41 & 9,49 & 8,32 \\
\hline Oil index & $\mathrm{mg} / \mathrm{l}$ & 0,1 & 0,2 & 0,3 & 0,8 & 0,6 & 0,2 \\
\hline $\begin{array}{c}\text { Phenol } \\
\text { index }\end{array}$ & $\mathrm{mg} / \mathrm{l}$ & 0,01 & 0,01 & 0,01 & 0,01 & 0,01 & 0,01 \\
\hline $\begin{array}{c}\text { Benzo(a) } \\
\text { pyrene }\end{array}$ & $\mu \mathrm{g} / \mathrm{l}$ & 0,0025 & 0,0140 & 0,0170 & 0,0120 & 0,0110 & 0,0025 \\
\hline $\mathrm{WWA}$ & $\mu \mathrm{g} / \mathrm{l}$ & 0,010 & 0,036 & 0,038 & 0,024 & 0,024 & 0,010 \\
\hline Benzene & $\mu \mathrm{g} / \mathrm{l}$ & 0,5 & 0,5 & 0,5 & 0,5 & 0,5 & 0,5 \\
\hline $\mathrm{Zn}$ & $\mathrm{mg} / \mathrm{l}$ & 0,036 & 0,016 & 0,15 & 0,17 & 0,013 & 0,24 \\
\hline $\mathrm{Cd}$ & $\mu \mathrm{g} / \mathrm{l}$ & 0,1 & 0,1 & 0,36 & 0,44 & 0,1 & 0,77 \\
\hline $\mathrm{Cu}$ & $\mu \mathrm{g} / \mathrm{l}$ & 2,3 & 3,6 & 24,0 & 69,0 & 2,2 & 76,0 \\
\hline $\mathrm{Pb}$ & $\mu \mathrm{g} / \mathrm{l}$ & 1,5 & 1,0 & 11,0 & 35,0 & 1,0 & 81,0 \\
\hline Phosphates & $\mathrm{mg} / \mathrm{l}$ & 1,61 & 1,53 & 0,15 & 0,09 & 0,09 & 0,2 \\
\hline
\end{tabular}

$\mathrm{pH}$ value

Experiment $1 \square$ Experiment 2

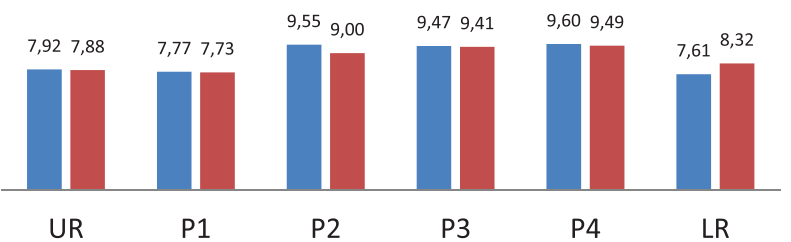

Fig. 4. Comparison of $p H$ reaction of water in the experiments 1 and 2

\section{WWA contentration $[\mu \mathrm{g} / \mathrm{I}]$}

Experiment 1 Experiment 2

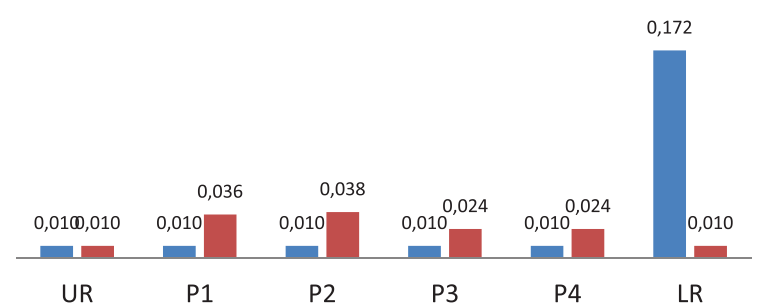

Fig. 5. Comparison of WWA concentration in water in the experiments 1 and 2 


\section{Cu concentration $[\mu \mathrm{g} / \mathrm{l}]$}

Experiment 1 Experiment 2

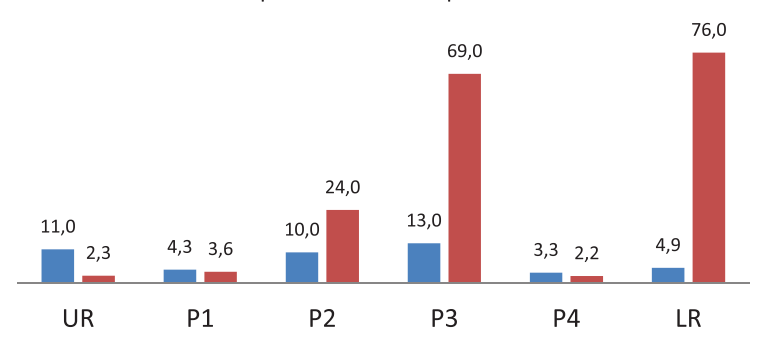

Fig. 6. Comparison of $\mathrm{Cu}$ concentration in water in the experiments 1 and 2

Phosphate concentration $[\mathrm{mg} / \mathrm{l}]$

Experiment 1 Experiment 2

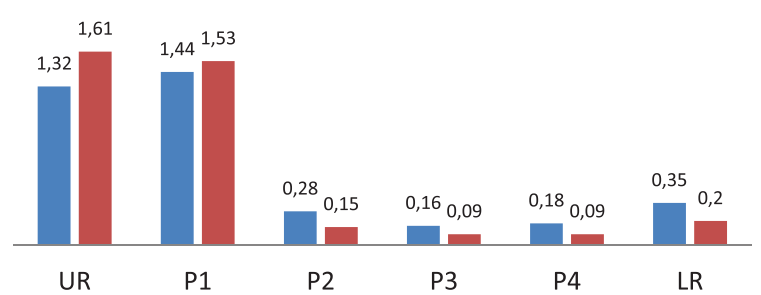

Fig. 7. Comparison of phosphate concentration in water in the experiments 1and 2

The results of the tests on organic contamination may be considered somewhat astonishing, namely : the sudden jump of WWA values (Fig . 5) and benzo(a)pyrene content in seepage in the test 1 , as well as the detecting some ( minute ) concentrations of both the indices inside the dike in the test 2 . The first above mentioned issue may be explained by a random external fuel contamination (from a motor pump delivering water to the upper reservoir), especially as the effect does not occur in the test 2 . As far as the second issue is concerned, i.e. a rise in concentration of both contaminations over the detection limit, its source is hard to identify and its cause should be search for outside the dike body, taking into account their lack in the preceding test. An analysis of meteorological data makes it possible to form a hypothesis on migration of the above mentioned compounds by air from a nearby oil refinery (about only $8 \mathrm{~km}$ distant in WNW direction). Apparently, during the fortnight preceding the test 1 no significant rainfall (of total precipitation of about 5 $\mathrm{mm}$ ) was observed, however during the fortnight preceding the test 2 the rainfall of about $50 \mathrm{~mm}$ occurred at prevailing west and north- west winds (exactly from the direction of the oil refinery ). Hence, probably, the seeping water introduced the organic contaminations contained in the rainfall ( whose drops absorbed contaminations from the refinery area) into the dike body, which were revealed in the test 2 . Their lack in the water delivered to the upper reservoir ( UR) results from their lack in the water taken from the Dead Vistula to fill the reservoir. Worth stressing that the measured quantities of contaminations of the water inside the dike are on the safe side of the standard permissible values.
It is also hard to explain the discrepancy in measurements of concentration of $\mathrm{Cu}$ compounds ( and also of $\mathrm{Pb}$ ones ) in both the experiments (Fig.6, Tab. 6 and 7). Whereas the first of them shows relatively small variations of the above mentioned concentrations (in the range of $3,3 \div 11,0 \mu \mathrm{g} / \mathrm{l}$ ), the other shows much greater variation of the concentrations (from 2,2 to $76,0 \mu \mathrm{g} / \mathrm{l}$ ) and the peaks in the points P3 and LR. Inverse trends are observed in the case of $\mathrm{Cd}$ and $\mathrm{Zn}$ - here the bigger concentrations were found in the experiment 1 . In comparison with the reference values (Tab. 3 and 4), the measured values generally satisfy the standards and only in a few cases they slightly exceed the permissible concentrations. It should be mentioned that the comparison concerns the standards for potable and clean surface waters, hence the obtained results may be considered very satisfactory, not indicating occurrence of any environmental hazards.

A favourable factor in the context of low content of heavy metals in seepage, is a slightly alkaline reaction of the dike body, and, consequently, the water inside the dike ( $\mathrm{pH} 9 \div 10$ ). The laboratory tests confirm that such conditions do not allow for excessively fast rate of leaching such elements as : $\mathrm{Pb}, \mathrm{Cd}$, $\mathrm{Cu}$ from the composite soil [15].

An interesting observation is also the effect of purifying influence of the dike as far as phosphates are concerned. In both the experiments a decreasing concentration of phosphates can be observed during flow of the water through the dike (Fig. 7), which is favourable in the context of lowering the eutrophication.

\section{SUMMARY}

The performed tests on the experimental dike showed that it is hard to obtain repeatability of test results at a lack of control over all boundary conditions ( possible infiltration of rain water which may change chemical properties of building material of the dike, and the filtering of river water through the dike). On the other hand, it was possible to verify, in natural scale, a lack of environmental hazards resulting from the use of the materials, tested in advance, and classified as by-products (silt winning, ash). However it should be stressed that the conducted investigations constitute only a contribution to discussion on the environmental aspects of the materials of the kind and therefore they should be continued in the future.

A subsequent research step may be directed toward the developing of a numerical model of the phenomenon of water filtering through the dike, which would take into account the flow in conditions of not entire saturation of the soil [6] as well as the phenomenon of transportation at accounting for adsorption of contaminations on soil particles. Such task should not be counted among trivial ones, and a significant potential for its solving may be attributed to the tools based on the meshless methods such as e.g. the Meshless Local Petrov-Galerkin method [16],or the Smoothed Particle Hydrodynamics $[17 \div 20]$. Such approach will be used in the next steps of the research in question. 
Obviously, soil -ash composites, like other composite materials used in other domains of building industry[21], constitute a valuable structural material whose potential has not been so far thoroughly tested and exploited.

\section{ACKNOWLEDGEMENT}

This paper has been prepared on the basis of the research conducted in the frames of the DredgDikes project financially supported by EU resources in the frames of the South Baltic research fund $(E R D F)$ for the years $2010 \div 2015$.

The scientific work has been partly supported from the financial resources, for the years $2011 \div 2014$, intended for realization of a scientific project in the frames of international cooperation.

\section{BIBLIOGRAPHY}

1. www.dredgdikes.eu

2. Bałachowski, L.; Sikora, Z.: Mechanical properties of bottom ash - dredged material mixtures in laboratory tests, Studia Geotechnica et Mechanica, 2013, 35(3) , pp. 3a11.

3. Zbigniew Sikora, Rafał Ossowski: Geotechnical Aspects of Dike Construction Using Soil-Ash Composites. Procedia Engineering , 2013, pp. $1029 \div 1035$

4. Olschewski J., Cantré S., Saathoff F., Duszyński R., Ossowski R: Overflowing tests at the Polish DredgDikes research dike - stability of the dike surface against erosion. Engineering Structures and Technologies, 2014 , pp. $159 \div 168$

5. Saathoff, F.; Cantré, S.; Sikora, Z. : South Baltic Guideline on the Application of Dredged Materials, Coal Combustion Products and Geosynthetics in Dike Construction, 2015, $100 \mathrm{p}$.

6. Szymkiewicz A.: Modelling water flow in unsaturated porous media: Accounting for nonlinear permeability and material heterogeneity. Springer, Heidelberg, 2013, 237p

7. Burdziakowski P., Janowski A., Kholodkov A., Matysik K., Matysik M., Przyborski M., Szulwic J., Tysiąc P., Wojtowicz A.: Maritime laser scanning as the source for spatial data.

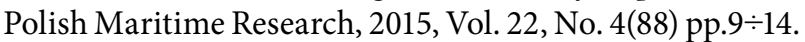

8. Grelowska G., Kozaczka E.: Underwater Acoustic Imaging of the Sea. Archives of Acoustics, 2014, Vol. 39, No. 4, pp. $439 \div 452$

9. Grelowska G., Kozaczka E.: Nonlinear properties of the Gotland Deep - Baltic Sea. Archives of Acoustics , 2015, Vol. 40, No. 4, pp. $595-\div 600$
10. Kozaczka E.: Acoustics waves in the sea. Archives of Acoustics , 2013 , Vol. 38, No. 3 pp. $441 \div 442$

11. Kozaczka E., Grelowska G., Kozaczka S.: Detection of Objects Buried in the Sea Bottom with the Use of Parametric Echosounder, Archives of Acoustics, 2013,Vol. 38, No. 1 , pp. $99 \div 104$

12. Kothe H.: Dredging and the environment - international guidance for best practice, PIANC , 125th Anniversary Celebration in Asia, Nagoya 2010.

13. vom Berg W., Feuerborn H-J.: Coal Combustion Products in Europe - valuable raw materials for the construction industry. Concrete Plant International , 2006, Special Print 04/06

14. Kabata-Pendias A. et al.: Assessment of degree of contamination of soils and plants by heavy metals and sulphur ( in Polish). General guidelines for agriculture industry, IUNG, Puławy, 1993

15. Komonweeraket K., Cetin B. et al.: Effects of pH on the leaching mechanisms of elements from fly ash mixed soils, FUEL , 2015 ,Vol. 140 , pp. $788 \div 802$

16. Ossowski R.: Local heaviside weighted mlpg meshless method approach to extended flamant problem using radial basis functions, Studia Geotechnica et Mechanica , 2008, pp. $173 \div 180$

17. Liu G. R. and Liu M. B.: Smoothed particle hydrodynamics: a mesh-free particle method, World Scientific, 2003

18. Szewc K., Taniere A., Pozorski J., Minier J.: A study on application of Smoothed Particle Hydrodynamics to multiphase flows, International Journal of Nonlinear Sciences and Numerical Simulation, 2012 ?

19. Szewc K., Pozorski J., Minier J.: Analysis of the incompressibility constraint in the smoothed particle hydrodynamics method, Int. J. for Numerical Meth. in Eng., 2012, Vol. 92, No. 4

20. Szewc K., Pozorski J., Taniere A.: Modeling of natural convection with Smoothed Particle Hydrodynamics: NonBoussinesq formulation, International Journal of Heat and Mass Transfer , 2011 , Vol. 54, pp. $4807 \div 4816$

21. Miśkiewicz M, Daszkiewicz K., Ferenc T. Witkowski W and Chróścielewski J.: Experimental tests and numerical simulations of full scale composite sandwich segment of a foot-and cycle-bridge, Advances in Mechanics: Theoretical, Computational and Interdisciplinary Issues - Kleiber et al. (Eds), Taylor \& Francis Group, London, 2016, pp. 401 $\div 404$. 
22. The Decree of Ministry of the Environment, of September 1,2016 , on the method of conducting assessment of soil surface contamination (in Polish), (Dz.U.2016 poz.1395)

23. The Decree of Ministry of the Environment, of November 9,2011 , on the method of classification of the state of homogenous areas of surface waters and environment quality standards for priority substances (in Polish), (Dz.U.2011.257.1545)

24. The Decree of Ministry of the Environment, of November 27,2002 , on the requirements which are to be satisfied by surface waters intended for the delivering as potable to population (in Polish), (Dz.U.2002.204.1728)

\section{CONTACT WITH THE AUTHOR}

Rafał Ossowski

Gdańsk University of Technology

11/12 Narutowicza St.

80 - 233 Gdańsk

POLAND 